\title{
Beta-Blocker Drug Therapy Reduces Secondary Cancer Formation in Breast Cancer and Improves Cancer Specific Survival
}

\author{
Desmond G. Powe ${ }^{1}$, Melanie J. Voss ${ }^{2}$, Kurt S. Zänker ${ }^{2}$, Hany O. Habashy ${ }^{3}$, Andrew \\ R. Green ${ }^{3}$, Ian O. Ellis ${ }^{3} \&$ Frank Entschladen ${ }^{2}$ \\ 1 Department of Cellular Pathology, Queen's Medical Centre, Nottingham University Hospitals NHS Trust, Nottingham, NG7 \\ $2 \mathrm{UH}, \mathrm{UK}$ and The John van Geest Cancer Research Centre School of Science and Technology, Nottingham Trent University, \\ Clifton Lane, Nottingham NG11 8NS UK \\ 2 Institute of Immunology, University of Witten/Herdecke, DE-58448, Witten, Germany \\ ${ }^{3}$ School of Molecular Medical Sciences, University of Nottingham, Nottingham, NG7 2UH, UK \\ Correspondence to: Desmond G. Powe, e-mail: des.powe@nottingham.ac.uk
}

Keywords: Beta-blockers, cancer, therapy

Received: August 10, 2010, Accepted: October 18, 2010, Published: October 19, 2010

Copyright: ( Powe et al. This is an open-access article distributed under the terms of the Creative Commons Attribution License, which permits unrestricted use, distribution, and reproduction in any medium, provided the original author and source are credited.

ABSTRACT:

Laboratory models show that the beta-blocker, propranolol, can inhibit norepinephrine-induced breast cancer cell migration. We hypothesised that breast cancer patients receiving beta-blockers for hypertension would show reduced metastasis and improved clinical outcome. Three patient subgroups were identified from the medical records of 466 consecutive female patients (median age 57, range 28-71) with operable breast cancer and follow-up (>10 years). Two subgroups comprised 43 and 49 hypertensive patients treated with beta-blockers or other antihypertensives respectively, prior to cancer diagnosis. 374 patients formed a nonhypertensive control group. Metastasis development, disease free interval, tumour recurrence and hazards risk were statistically compared between groups. KaplanMeier plots were used to model survival and DM. Beta-blocker treated patients showed a significant reduction in metastasis development $(p=0.026)$, tumour recurrence $(p=0.001)$, and longer disease free interval $(p=0.01)$. In addition, there was a $57 \%$ reduced risk of metastasis (Hazards ratio $=0.430 ; 95 \% \mathrm{CI}=0.200-0.926$, $\mathrm{p}=0.031$ ), and a $71 \%$ reduction in breast cancer mortality after 10 years (Hazards ratio $=0.291 ; 95 \% \mathrm{CI}=0.119-0.715, \mathrm{p}=0.007)$. This proof-of-principle study showed beta-blocker therapy significantly reduces distant metastases, cancer recurrence, and cancer-specific mortality in breast cancer patients suggesting a novel role for beta-blocker therapy. A larger epidemiological study leading to randomised clinical trials is needed for breast and other cancer types including colon, prostate and ovary.

\section{INTRODUCTION}

Although an estimated 38,000 [1] patients are diagnosed with breast cancer in the US each year death rates are declining in part due to adjuvant therapies including the use of ER-antagonists and anti-HER2 (trastuzumab) therapy [2-4]. Nonetheless, approximately $30 \%$ of treated $\mathrm{BC}$ patients develop distant metastases [5] and these significantly account for $90 \%$ of breast cancer deaths [6]. Consequently, therapeutic strategies are needed that target metastasis $[7,8]$.

Metastasis formation involves migration of malignant cells from the primary tumour via lymphatic or blood vessel routes with the process being tightly regulated by exogenous cell signalling molecules, including ligands to G protein-coupled receptors (GPCRs) such as neurotransmitters and chemokines $[9,10]$. In previous in vitro cell migration studies we have shown that the stress catecholamine hormone norepinephrine is a potent inducer of migratory activity in carcinoma cell lines of colon [11], prostate [12], ovarian cancer cells [13] and breast [14] tissue origin, and this finding has been confirmed in a mouse model [15]. Moreover, we have shown that cell migration is mediated by adrenergic 
receptors (AR) and that the process is inhibited by the beta-blocker adrenergic receptor antagonist drug propranolol which is non-selective for $\beta 1 \mathrm{AR}$ and $\beta 2 \mathrm{AR}$ $[11,12,15]$. Additional support for the therapeutic benefit of beta-blockers is provided by recent studies showing propranolol can reduce proliferation in human pancreatic cell lines $[16,17]$.

Beta-blocker drugs along with ACE-inhibitors, calcium channel antagonists, imidazoline receptor antagonists, and diuretics are clinically well characterized for the therapeutic treatment of hypertension and are proven in reducing life-threatening cerebrovascular events $[18,19]$. Epidemiologic studies confirm that beta-blocker treatment per se has no effect in causing or promoting cancer growth giving reassurance for their continued clinical use [20, 21].

In the present study we hypothesised that patients started on and maintained with antihypertensive betablocker therapy prior to their breast cancer diagnosis would show reduced distant metastasis formation compared to non-hypertensive breast cancer patients or those treated with other antihypertensive drugs.

\section{RESULTS}

\section{Clinical Correlations in Patients Treated with Beta- Blocker Drugs compared to other Hypertensive and Non-hypertensive Breast Cancer Patients}

Data was obtained for 466 breast cancer patients used

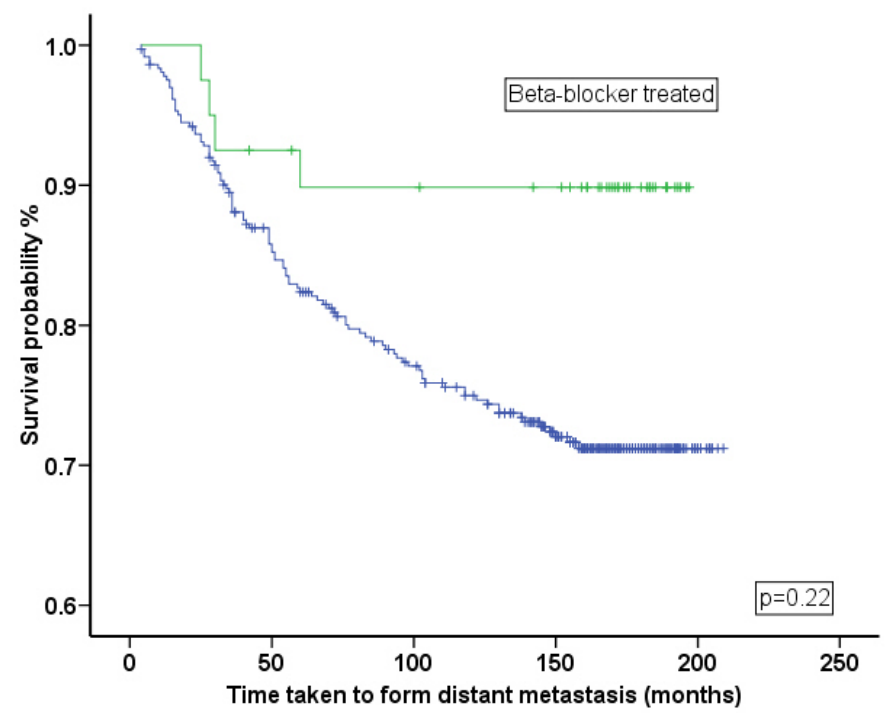

in this study and their characteristics are shown in Tables 1a-d. A total of 92 (19.7\%) patients had hypertension diagnosed prior to breast cancer diagnosis and were therapeutically treated using a range of antihypertensives including beta-blockers, ACE inhibitors, $\mathrm{Ca}^{+}$antagonists, imidazoline receptor antagonists or diuretics (Table 2). In particular, 43/92 (46.7\%) of this hypertensive subgroup (median age 57 years, range 39-69) received beta-blocker drugs while the remaining 49/92 (53.3\%) patients received other antihypertensive drugs. The latter group significantly differed in showing increased median age of 62 years (range 47-70) compared to the non-hypertensive patient subgroup whose median age was 54.5 years (range 28-71). In addition, the non-beta-blocker treated antihypertensive subgroup contained an increased proportion of postmenopausal patients (Table 1c) Otherwise, no significant difference was seen in tumour stage, tumour size, grade, type, vascular invasion, Nottingham Prognostic Index (NPI) or AT between the three patient subgroups.

Patients receiving beta-blockers showed a significant reduction in formation of distant metastasis $(\chi 2=4.986$, $\mathrm{p}=0.026)$ and tumour recurrence $(\chi 2=13.091, \mathrm{p}=0.001)$ compared to non-hypertensive $\mathrm{BC}$ control patients (Table 3).

\section{Hypertensive Breast Cancer Patients Treated with Beta-Blockers Compared with Other Antihypertensive Drugs}

Beta-blocker treated breast cancer patients differed significantly to patients receiving other antihypertensives $(\chi 2=4.852, \mathrm{p}=0.028)$ in showing reduced development

Figure 1a: Hypertensive BC patients therapeutically treated with beta-blockers showed significantly (p=0.022) longer times before acquiring metastases compared to non-treated patients.

Figure 1b. Hypertensive BC patients receiving beta-blocker therapy showed significantly $(p=0.011)$ improved 10 year survival rates compared to non-treated patients. 
of distant metastasis $(5 / 43(11.6 \%))$ compared to their counterparts $(15 / 49(30.6 \%))$ (Table 3$)$. In addition, the beta-blocker treated subgroup showed significantly reduced tumour recurrence $(\chi 2=7.264, p=0.026$; Table 1b).

\section{PATIENT OUTCOME}

\section{Univariate analysis:}

Kaplan-Meier modelling with log rank testing showed beta-blocker treated patients had longer distant

\begin{tabular}{|c|c|c|c|c|}
\hline Variable & $\begin{array}{c}\text { Number (\%) } \\
\text { Control BC } \\
\text { patients }\end{array}$ & $\begin{array}{c}\text { Number (\%) } \\
\text { BB-treated } \\
\text { patients }\end{array}$ & $\chi^{2}$ & p-value \\
\hline \multicolumn{5}{|l|}{ Patients' Age } \\
\hline$<40$ & $22(5.9)$ & $1(2.3)$ & \multirow{4}{*}{4.079} & \multirow{4}{*}{0.253} \\
\hline $40-50$ & $117(31.3)$ & $9(20.9)$ & & \\
\hline $51-60$ & $126(33.7)$ & $20(46.5)$ & & \\
\hline$>60$ & $109(29.1)$ & $13(30.2)$ & & \\
\hline \multicolumn{5}{|l|}{ Primary tumour size } \\
\hline$\leq 1.5 \mathrm{~cm}$ & $134(35.9)$ & $14(33.3)$ & \multirow{2}{*}{0.111} & \multirow{2}{*}{0.740} \\
\hline$>1.5 \mathrm{~cm}$ & $239(64.1)$ & $28(66.7)$ & & \\
\hline \multicolumn{5}{|l|}{ Tumour stage } \\
\hline 1 & $250(67.0)$ & $31(73.8)$ & \multirow{3}{*}{1.176} & \multirow{3}{*}{0.555} \\
\hline 2 & $89(23.9)$ & $9(21.4)$ & & \\
\hline 3 & $34(9.1)$ & $2(4.8)$ & & \\
\hline \multicolumn{5}{|l|}{ Grade } \\
\hline 1 & $75(20.2)$ & $7(16.7)$ & \multirow{3}{*}{2.205} & \multirow{3}{*}{0.332} \\
\hline 2 & $129(34.7)$ & $11(26.2)$ & & \\
\hline 3 & $168(45.2)$ & $24(57.1)$ & & \\
\hline \multicolumn{5}{|l|}{ NPI } \\
\hline Poor & $43(11.6)$ & $6(14.3)$ & \multirow{3}{*}{0.270} & \multirow{3}{*}{0.874} \\
\hline Moderate & $212(57.1)$ & $23(54.8)$ & & \\
\hline Good & $116(31.3)$ & $13(31.0)$ & & \\
\hline \multicolumn{5}{|c|}{ Development of Recurrence } \\
\hline No & $220(59.3)$ & $32(74.4)$ & \multirow{2}{*}{13.091} & \multirow{2}{*}{0.001} \\
\hline Positive & $151(40.7)$ & $10(23.3)$ & & \\
\hline \multicolumn{5}{|l|}{ Vascular invasion } \\
\hline Negative & $227(61.5)$ & $27(62.8)$ & \multirow{3}{*}{1.788} & \multirow{3}{*}{0.409} \\
\hline Probable & $40(10.8)$ & $2(4.7)$ & & \\
\hline Definite & $102(27.6)$ & $14(32.6)$ & & \\
\hline \multicolumn{5}{|l|}{ Tumour type } \\
\hline Ductal/NST & $200(54.6)$ & $27(62.8)$ & \multirow{6}{*}{7.433} & \multirow{6}{*}{0.283} \\
\hline Lobular & $42(11.5)$ & $4(9.3)$ & & \\
\hline $\begin{array}{l}\text { Tubular and Tubular } \\
\text { mixed }\end{array}$ & $78(21.3)$ & $8(18.6)$ & & \\
\hline Medullary & $11(3.0)$ & $1(2.3)$ & & \\
\hline Other special types* & $10(2.7)$ & $2(4.7)$ & & \\
\hline Mixed** & $24(6.6)$ & $0(0)$ & & \\
\hline \multicolumn{5}{|l|}{ Menopausal status } \\
\hline Premenopausal & $149(39.8)$ & $9(20.9)$ & \multirow{2}{*}{5.860} & \multirow{2}{*}{0.015} \\
\hline Postmenopausal & $225(60.2)$ & $34(79.1)$ & & \\
\hline
\end{tabular}

Table 1a: Characteristics for breast cancer patients therapeutically treated with beta-blockers (BB) compared to control breast cancer (BC) patients, excluding patients treated with other types of antihypertensive drugs. 


\begin{tabular}{|c|c|c|c|c|}
\hline Variable & $\begin{array}{c}\text { Number (\%) } \\
\text { BC treated with } \\
\text { other } \\
\text { antihypertensives }\end{array}$ & $\begin{array}{l}\text { Number (\%) } \\
\text { BB-Treated }\end{array}$ & $\chi^{2}$ & p-value \\
\hline \multicolumn{5}{|l|}{ Patients' Age } \\
\hline$<40$ & $0(0)$ & $1(2.3)$ & \multirow{4}{*}{6.507} & \multirow{4}{*}{0.089} \\
\hline $40-50$ & $10(20.4)$ & $9(20.9)$ & & \\
\hline $51-60$ & $13(26.5)$ & $20(46.5)$ & & \\
\hline$>60$ & $26(53.1)$ & $13(30.2)$ & & \\
\hline \multicolumn{5}{|l|}{ Primary tumour size } \\
\hline$\leq 1.5 \mathrm{~cm}$ & $19(39.6)$ & $14(33.3)$ & \multirow{2}{*}{0.377} & \multirow{2}{*}{0.539} \\
\hline$>1.5 \mathrm{~cm}$ & $29(60.4)$ & $28(66.7)$ & & \\
\hline \multicolumn{5}{|l|}{ Tumour stage } \\
\hline 1 & $31(66.0)$ & $31(73.8)$ & \multirow{3}{*}{0.817} & \multirow{3}{*}{0.665} \\
\hline 2 & $12(25.5)$ & $9(21.4)$ & & \\
\hline 3 & $4(8.5)$ & $2(4.8)$ & & \\
\hline \multicolumn{5}{|l|}{ Grade } \\
\hline 1 & $12(25.0)$ & $7(16.7)$ & \multirow{3}{*}{2.215} & \multirow{3}{*}{0.330} \\
\hline 2 & $16(33.3)$ & $11(26.2)$ & & \\
\hline 3 & $20(41.7)$ & $24(57.1)$ & & \\
\hline \multicolumn{5}{|l|}{ NPI } \\
\hline Poor & $5(10.2)$ & $6(14.3)$ & \multirow{3}{*}{1.065} & \multirow{3}{*}{0.587} \\
\hline Moderate & $24(49.0)$ & $23(54.8)$ & & \\
\hline Good & $20(40.8)$ & $13(31.0)$ & & \\
\hline \multicolumn{5}{|c|}{ Development of Recurrence } \\
\hline No & $25(51.0)$ & $32(74.4)$ & \multirow{2}{*}{7.264} & \multirow{2}{*}{0.026} \\
\hline Positive & $24(49.0)$ & $10(23.3)$ & & \\
\hline \multicolumn{5}{|l|}{ Vascular invasion } \\
\hline Negative & $30(61.2)$ & $27(62.8)$ & \multirow{3}{*}{1.811} & \multirow{3}{*}{0.404} \\
\hline Probable & $6(12.2)$ & $2(4.7)$ & & \\
\hline Definite & $13(26.5)$ & $14(32.6)$ & & \\
\hline \multicolumn{5}{|l|}{ Tumour type } \\
\hline Ductal/NST & $26(53.1)$ & $27(62.8)$ & \multirow{6}{*}{8.269} & \multirow{6}{*}{0.309} \\
\hline Lobular & $3(6.1)$ & $4(9.3)$ & & \\
\hline $\begin{array}{l}\text { Tubular and Tubular } \\
\text { mixed }\end{array}$ & $15(30.6)$ & $8(18.6)$ & & \\
\hline Medullary & $2(4.1)$ & $1(2.3)$ & & \\
\hline Other special types* & $0(0)$ & $2(4.7)$ & & \\
\hline Mixed** & $2(4.1)$ & $0(0)$ & & \\
\hline \multicolumn{5}{|l|}{ Menopausal status } \\
\hline Premenopausal & $12(24.5)$ & $9(20.9)$ & \multirow{2}{*}{0.165} & \multirow{2}{*}{0.685} \\
\hline Postmenopausal & $37(75.5)$ & $34(79.1)$ & & \\
\hline
\end{tabular}

Table 1b: Characteristics for breast cancer patients therapeutically treated with beta-blockers (BB) compared to breast cancer $(\mathrm{BC})$ patients treated with other antihypertensive drugs. 


\begin{tabular}{|c|c|c|c|c|}
\hline Variable & $\begin{array}{c}\text { Number (\%) } \\
\text { Control BC } \\
\text { patients }\end{array}$ & $\begin{array}{c}\text { Number (\%) } \\
\text { BC treated with } \\
\text { other } \\
\text { antihypertensives }\end{array}$ & $\chi^{2}$ & p-value \\
\hline \multicolumn{5}{|l|}{ Patients' Age } \\
\hline$<40$ & $22(5.9)$ & $0(0)$ & \multirow{4}{*}{12.708} & \multirow{4}{*}{0.005} \\
\hline $40-50$ & $115(30.7)$ & $10(20.4)$ & & \\
\hline $51-60$ & $127(34.0)$ & $131(26.5)$ & & \\
\hline$>60$ & $110(29.4)$ & $26(53.1)$ & & \\
\hline \multicolumn{5}{|l|}{ Primary tumour size } \\
\hline$\leq 1.5 \mathrm{~cm}$ & $134(35.9)$ & $19(39.6)$ & \multirow{2}{*}{0.246} & \multirow{2}{*}{0.620} \\
\hline$>1.5 \mathrm{~cm}$ & $239(64.1)$ & $29(60.4)$ & & \\
\hline \multicolumn{5}{|l|}{ Tumour stage } \\
\hline 1 & $249(66.9)$ & $31(66.0)$ & \multirow{3}{*}{0.069} & \multirow{3}{*}{0.966} \\
\hline 2 & $89(23.9)$ & $12(25.5)$ & & \\
\hline 3 & $34(9.1)$ & $4(8.5)$ & & \\
\hline \multicolumn{5}{|l|}{ Grade } \\
\hline 1 & $74(19.9)$ & $12(25.0)$ & \multirow{3}{*}{0.709} & \multirow{3}{*}{0.702} \\
\hline 2 & $128(34.4)$ & $16(33.3)$ & & \\
\hline 3 & $170(45.7)$ & $20(41.7)$ & & \\
\hline \multicolumn{5}{|l|}{ NPI } \\
\hline Poor & $43(11.6)$ & $5(10.2)$ & \multirow{3}{*}{1.917} & \multirow{3}{*}{0.384} \\
\hline Moderate & $213(57.4)$ & $24(49.0)$ & & \\
\hline Good & $115(31.0)$ & $20(40.8)$ & & \\
\hline \multicolumn{5}{|c|}{ Development of Recurrence } \\
\hline No & $218(58.8)$ & $25(51.0)$ & \multirow{2}{*}{1.063} & \multirow{2}{*}{0.302} \\
\hline Positive & $153(41.2)$ & $24(49.0)$ & & \\
\hline \multicolumn{5}{|l|}{ Vascular invasion } \\
\hline Negative & $228(61.8)$ & $30(61.2)$ & \multirow{3}{*}{0.057} & \multirow{3}{*}{0.972} \\
\hline Probable & $41(11.1)$ & $6(12.2)$ & & \\
\hline Definite & $100(27.1)$ & $13(26.5)$ & & \\
\hline \multicolumn{5}{|l|}{ Tumour type } \\
\hline Ductal/NST & $201(54.9)$ & $26(53.1)$ & \multirow{6}{*}{12.228} & \multirow{6}{*}{0.093} \\
\hline Lobular & $42(11.5)$ & $3(6.1)$ & & \\
\hline $\begin{array}{l}\text { Tubular and Tubular } \\
\text { mixed }\end{array}$ & $78(21.3)$ & $15(30.6)$ & & \\
\hline Medullary & $11(3.0)$ & $2(4.1)$ & & \\
\hline Other special types* & $9(2.5)$ & $0(0)$ & & \\
\hline Mixed** & $24(6.6)$ & $2(4.1)$ & & \\
\hline \multicolumn{5}{|l|}{ Menopausal status } \\
\hline Premenopausal & $147(39.3)$ & $12(24.5)$ & \multirow{2}{*}{4.053} & \multirow{2}{*}{0.044} \\
\hline Postmenopausal & $229(60.7)$ & $37(75.5)$ & & \\
\hline
\end{tabular}

Table 1c: Characteristics for breast cancer patients therapeutically treated with antihypertensive drugs (excluding beta blockers) compared to control breast cancer (BC) patients. 


\begin{tabular}{|c|c|c|c|c|}
\hline Variable & $\begin{array}{l}\text { Number (\%) } \\
\text { All other } \\
\text { patients }\end{array}$ & $\begin{array}{l}\text { Number (\%) } \\
\text { BB-Treated }\end{array}$ & $\chi^{2}$ & p-value \\
\hline \multicolumn{5}{|l|}{ Patients' Age } \\
\hline$<40$ & $22(5.2)$ & $1(2.3)$ & \multirow{4}{*}{3.926} & \multirow{4}{*}{0.270} \\
\hline $40-50$ & $127(30.1)$ & $9(20.9)$ & & \\
\hline $51-60$ & $139(32.9)$ & $20(46.5)$ & & \\
\hline$>60$ & $135(31.9)$ & $13(30.2)$ & & \\
\hline \multicolumn{5}{|l|}{ Primary tumour size } \\
\hline$\leq 1.5 \mathrm{~cm}$ & $153(36.3)$ & $14(33.3)$ & \multirow{2}{*}{0.150} & \multirow{2}{*}{0.699} \\
\hline$>1.5 \mathrm{~cm}$ & $268(63.7)$ & $28(66.7)$ & & \\
\hline \multicolumn{5}{|l|}{ Tumour stage } \\
\hline 1 & $281(66.9)$ & $31(73.8)$ & \multirow{3}{*}{1.190} & \multirow{3}{*}{0.552} \\
\hline 2 & $101(24.0)$ & $9(21.4)$ & & \\
\hline 3 & $38(9.0)$ & $2(4.8)$ & & \\
\hline \multicolumn{5}{|l|}{ Grade } \\
\hline 1 & $87(20.7)$ & $7(16.7)$ & \multirow{3}{*}{2.368} & \multirow{3}{*}{0.306} \\
\hline 2 & $145(34.5)$ & $11(26.2)$ & & \\
\hline 3 & $188(44.8)$ & $24(57.1)$ & & \\
\hline \multicolumn{5}{|l|}{ NPI } \\
\hline Poor & $48(11.4)$ & $6(14.3)$ & \multirow{3}{*}{0.305} & \multirow{3}{*}{0.859} \\
\hline Moderate & $236(56.2)$ & $23(54.8)$ & & \\
\hline Good & $136(32.4)$ & $13(31.0)$ & & \\
\hline \multicolumn{5}{|c|}{ Development of Recurrence } \\
\hline No & $244(58.2)$ & $33(78.6)$ & \multirow{2}{*}{6.854} & \multirow{2}{*}{0.010} \\
\hline Positive & $175(41.8)$ & $9(21.4)$ & & \\
\hline \multicolumn{5}{|l|}{ Vascular invasion } \\
\hline Negative & $257(61.5)$ & $27(62.8)$ & \multirow{3}{*}{1.877} & \multirow{3}{*}{0.391} \\
\hline Probable & $46(11.0)$ & $2(4.7)$ & & \\
\hline Definite & $115(27.5)$ & $14(32.6)$ & & \\
\hline \multicolumn{5}{|l|}{ Tumour type } \\
\hline Ductal/NST & $233(55.5)$ & $28(65.1)$ & \multirow{6}{*}{3.534} & \multirow{6}{*}{0.832} \\
\hline Lobular & $46(10.9)$ & $4(9.3)$ & & \\
\hline $\begin{array}{l}\text { Tubular and Tubular } \\
\text { mixed }\end{array}$ & $92(21.9)$ & $7(16.3)$ & & \\
\hline Medullary & $13(3.1)$ & $1(2.3)$ & & \\
\hline Other special types* & $10(2.4)$ & $2(4.6)$ & & \\
\hline Mixed** & $26(6.2)$ & $1(2.3)$ & & \\
\hline \multicolumn{5}{|l|}{ Menopausal status } \\
\hline Premenopausal & $160(37.9)$ & $11(25.6)$ & \multirow{2}{*}{2.553} & \multirow{2}{*}{0.110} \\
\hline Postmenopausal & $262(62.1)$ & $32(74.4)$ & & \\
\hline
\end{tabular}

*Includes Mucoid, invasive cribriform and invasive papillary carcinoma. ** Includes ductal/NST mixed with lobular or special types.

Table 1d: Characteristics for breast cancer patients therapeutically treated with beta-blockers (BB) compared to all other patients including those receiving other antihypertensive drug treatment. 
metastasis-free interval $(\log \operatorname{rank}(\mathrm{LR})=5.208, \mathrm{p}=0.022)$ (Fig 1a) and longer breast cancer specific survival (LR=6.479, $\mathrm{p}=0.011$ ) (Fig 1b), and longer disease free interval $(\mathrm{LR}=6.658, \mathrm{p}=0.011)$ when compared to nontreated breast cancer patients.

\section{Multivariate analysis:}

A multivariate Cox hazard model was used to determine the hazard ratio (HR) for predicting breast cancer specific survival and distant metastasis risk in patients receiving beta-blocker treatment compared to other significant breast cancer variables including tumour size, stage and grade. Patients receiving beta-blocker treatment had a $71 \%$ reduced risk of cancer-associated mortality $(\mathrm{HR}=0.291, \mathrm{CI}=0.119-0.715, \mathrm{p}=0.007)$. In addition, beta-blocker treated patients showed a $57 \%$ risk reduction in developing distant metastasis $(\mathrm{HR}=0.430$, $\mathrm{CI}=0.200-0.926, \mathrm{p}=0.031$; Table 4) compared to nontreated breast cancer patients.

\section{DISCUSSION}

\section{Evidence of the biological mechanism between stress hormones and tumour cell migration}

\begin{tabular}{|l|l|}
\hline Drug & Patient Numbers \\
\hline Beta-blockers & \\
\hline Atenolol & 25 \\
\hline Propranolol & 7 \\
\hline Bisoprolol & 7 \\
\hline Timolol & 4 \\
\hline \multicolumn{1}{|c|}{ Subtotal } & 43 \\
\hline Other drug treatments & \\
\hline Captopril (ACE-Inhibitor) & 6 \\
\hline Ramipril (ACE-Inhibitor) & 4 \\
\hline Enalapril (ACE-Inhibitor) & 3 \\
\hline Lisinopril (ACE-Inhibitor) & 3 \\
\hline & \\
\hline Nifedipine (Ca2+ antagonist) & 5 \\
\hline Amlodipine (Ca2+ antagonist) & 5 \\
\hline Nicardipine (Ca2+ antagonist) & 1 \\
\hline & \\
\hline $\begin{array}{l}\text { Moxonidine (Imidazoline } \\
\text { receptor antagonist) }\end{array}$ & 1 \\
\hline & \\
\hline Bendrofluazide (Diuretic) & 21 \\
\hline Subtotal & 49 \\
\hline Total & $\mathbf{9 2}$ \\
\hline
\end{tabular}

Table 2: Beta-blocker and other therapeutic drugs were used to treat breast cancer patients for pre-existing hypertension.

www.impactjournals.com/oncotarget
Tumour metastasis is a complex process and is associated with generally poor clinical outcome. Therapeutic strategies are needed that can prevent its occurrence, thereby prolonging patient life. The present study was performed to validate the putative role of betablocker adrenergic receptor antagonists in retarding the progress of breast cancer disease by reducing metastasis formation. We performed an epidemiological study of breast cancer patients with long term clinical follow up $(>10$ years) and showed that patients receiving antihypertensive beta-blocker drugs significantly benefit by a $57 \%$ reduction in distant metastasis formation and a $71 \%$ reduced risk of dying from breast cancer compared to control patients.

It is increasingly being recognised that stress can promote cancer progression through an indirect effect on the immune system [22]. Moreover, a biological mechanism of action has been proposed for the involvement of catecholamine stress hormones. It has been shown that norepinephrine can directly stimulate tumour cell migration and this effect is mediated by the beta-adrenergic receptor, $\beta 2 \mathrm{AR}$. High levels of $\beta_{2} \mathrm{AR}$ have been reported in human cell lines [11, 23, 24] and tumour samples [25] and importantly, we have shown that cell migration in a number of cancer models is inhibited by the beta-blocker adrenergic receptor antagonist, propranolol [11, 12, 14].

Proof-of principle epidemiological pilot study shows beta-blocker drugs reduce metastasis and tumour recurrence in patients with breast cancer, leading to an improvement in survival

The aim of the current study was to translate these findings into a clinical setting by testing the hypothesis that breast cancer patients receiving beta-blockers for preexisting hypertension would show a significant reduction in tumour metastasis with a consequent reduction in mortality.

In line with expectations, antihypertensive drug treatment was more frequently prescribed in older postmenopausal patients with no significant difference seen between the beta-blocker and other antihypertensive treatment subgroups. The beta-blocker treated subgroup was shown to have significantly $(57 \%)$ reduced risk of developing distant metastasis and tumour recurrence compared to patients receiving either no, or other types of, antihypertensive drugs. As a consequence of this, betablocker treated patients showed a significant increase in breast cancer specific survival and increased disease free interval. To the best of our knowledge, this is the first report highlighting the in vivo therapeutic benefits of beta-blockers in breast cancer patients, supporting the biological mechanism of norepinephrine-induced cell migration mediated by adrenergic receptor activation as shown in cell lines and animal models. These findings support recent epidemiological cancer studies that have 
shown adrenoceptor antagonists have the potential for providing a novel clinically effective therapeutic strategy in treating several different cancer types. Beta-blockers have been shown to reduce the incidence of endocrineregulated prostate cancer [26], but this beneficial effect is not just limited to inhibition of beta receptors because patients receiving alpha antagonists also show a reduced incidence of prostate [27] and bladder [28] cancer. Moreover, a generalised reduction in all cancer types has been reported in beta-blocker treated patients [29].

\section{Study limitations}

Several limitations apply to our epidemiological study including patient population size and factors that were not controlled for in using an existing patient dataset. In mitigation, the beta-blocker and other hypertensivetreated cohort were of approximately the same size and together accounted for approximately $20 \%$ of the total patient cohort. In addition, all patient subgroups were evenly matched for adjuvant therapy and age making it unlikely that this was the reason for the significant benefits seen in the beta-blocker group. A further possible limitation is that it is unknown (and impossible to establish) how long patients had breast cancer prior to a formal diagnosis, and so the duration required for beta-blockers to prevent development of metastases can not be calculated from this type of study. Some of these limitations can be addressed by performing a much larger epidemiological study, leading onto a randomised controlled clinical trial. The latter would determine a) If beta-blocker drugs can be used as a prophylactic for metastatic formation in breast cancer, b) The optimal adjuvant therapy dosage in breast cancer, c) Whether beta-blocker treatment is effective in clinically treating patients with other types of cancer, e.g. prostate, pancreatic and colonic cancer, suggested by our cell line models.

\section{Future studies}

The current study suggests that adrenoceptor antagonists have the potential for retarding breast cancer progression and improving clinical outcome. Additional studies are needed to assess the protein expression of adrenoceptors in breast and other cancer types to test if they can be used as prognostic and predictive biomarkers in determining clinical outcome and likely response to antagonist treatment.

\section{MATERIALS AND METHODS}

\section{Patient selection}

Therapeutic drug and medical history was obtained for 466 patients with stage I and II primary operable breast carcinoma, aged 71 years or less, who presented

\begin{tabular}{|c|c|c|c|c|}
\hline \multirow[t]{2}{*}{$\begin{array}{l}\text { Metastasis } \\
\text { formation }\end{array}$} & \multicolumn{2}{|c|}{$\begin{array}{c}\text { Treatment in breast } \\
\text { cancer groups }\end{array}$} & \multirow[t]{2}{*}{$\chi^{2}$} & \multirow[t]{2}{*}{ P-value } \\
\hline & $\begin{array}{c}\text { Non- } \\
\text { hypertensive } \\
\text { patients } \\
(\%) \\
\end{array}$ & $\begin{array}{c}\text { Beta-blocker } \\
\text { treated } \\
\text { hypertensives } \\
(\%)\end{array}$ & & \\
\hline Negative & $271(72.7)$ & $38(88.4)$ & \multirow{2}{*}{4.986} & \multirow{2}{*}{0.026} \\
\hline Positive & $102(27.3)$ & $5(11.6)$ & & \\
\hline & $\begin{array}{l}\text { Other treated } \\
\text { anti- } \\
\text { hypertensive } \\
\text { patients }(\%)\end{array}$ & $\begin{array}{c}\text { Beta-blocker } \\
\text { treated } \\
\text { patients } \\
(\%)\end{array}$ & & \\
\hline Negative & $34(69.4)$ & $38(88.4)$ & \multirow{2}{*}{4.852} & \multirow{2}{*}{0.028} \\
\hline Positive & $15(30.6)$ & $5(11.6)$ & & \\
\hline & $\begin{array}{c}\text { Non } \\
\text { hypertensive } \\
\text { BC patients } \\
(\%)\end{array}$ & $\begin{array}{l}\text { Other anti- } \\
\text { hypertensive } \\
\text { patients }\end{array}$ & & \\
\hline Negative & $271(72.7)$ & $34(69.4)$ & \multirow{2}{*}{0.231} & \multirow{2}{*}{0.631} \\
\hline Positive & $102(27.3)$ & $15(30.6)$ & & \\
\hline
\end{tabular}

Table 3: Two hypertensive breast cancer (BC) patient groups comprising those treated with beta-blockers and non-beta blocker antihypertensive drugs were compared with a non-hypertensive non-treated BC group for formation of distant metastases. 
consecutively to the Nottingham City Hospital between 1987 and 1994 as previously reported [30]. Patients were placed into one of three subgroups according to whether they received (1) beta-blocker treatment for hypertension, (2) other antihypertensive drug treatment, or were (3) normotensive. To qualify for subgroup (1) or (2) membership, patients needed to have been receiving antihypertensive therapy for at least 1 year prior to breast cancer diagnosis. This criterion was applied to minimise differences due to length of drug treatment; patients that received hypertensive drugs for less than 1 year were excluded because the primary objective tested was that beta-blockers may have a role in preventing metastasis formation in early stage breast cancer rather than eradicating or neutralising established primary and secondary cancers.

Patient's clinical and pathologic data was available including age, histologic tumour type, primary tumour size, lymph node status and histologic grade, Nottingham prognostic index (NPI), vascular invasion (VI), and radio/ chemotherapy. Patients were considered for adjuvant therapy (AT) in a standardised scheduled on the basis of prognostic and predictive factor status including Nottingham Prognostic Index (NPI) [31], oestrogen receptor- $\alpha(E R \alpha)$ status, and menopausal status. Patients with a good prognostic index $(\mathrm{NPI} \leq 3.4)$ did not receive AT. Hormonal therapy (HT) was prescribed to patients with ER $\alpha+$ tumours and NPI scores of $>3.4$ (moderate and poor prognostic groups). Pre-menopausal patients within the moderate and poor prognostic groups were candidates for CMF (Cyclophosphamide, Methotrexate, and 5-Flourouracil) chemotherapy; patients with ER $\alpha+$ tumour were also offered HT. Conversely, postmenopausal patients with moderate or poor NPI and ER $\alpha+$ were offered HT, while ER $\alpha$ - patients received CMF. Data has been accrued on a prospective basis for breast cancer specific survival (BCSS), disease free interval (DFI), formation of distant metastases (DM) and local tumour recurrence. BCSS was defined as the time (in months) from the date of the primary surgical treatment to the time of death from breast cancer. DFI was defined as the interval (in months) from the date of the primary surgical treatment to the first locoregional or distant metastasis. Mean follow-up time was 124 months for the study cohort.

\section{Univariate and Multivariate Statistics}

The clinical outcome in three patient cohorts (betablocker drug treated, other antihypertensive drug treated, and non-hypertensive breast cancer groups) was tested using Kaplan-Meier plots with log rank test to assess significance including breast cancer specific survival, disease free interval, and distant metastasis formation. Other associations including tumour recurrence was tested using Chi square or Fishers exact test. Multivariate Cox regression analysis was used to evaluate the hazard ratio and any independent prognostic effect of the variables using 95\% confidence interval (Version 15, SPSS Inc, IL, USA). A p-value of $<0.05$ was considered significant.

\section{ACKNOWLEDGEMENTS}

We thank the ministry of higher education (Egypt) for funding HO Habashy. Supported in part by Fritz-BenderFoundation, Munich. In addition, the kind assistance of Mrs Pat Ward and the Medical Records department is acknowledged.

\section{CONFLICT OF INTEREST STATEMENT}

The authors do not have any conflicts of interest to declare.

\begin{tabular}{|c|c|c|c|c|}
\hline Parameter & HR & p-value & \multicolumn{2}{|c|}{ 95\% Confidence Interval } \\
\hline & & & Lower & Upper \\
\hline \multicolumn{5}{|l|}{ BCSS } \\
\hline \multirow{4}{*}{$\begin{array}{l}\text { Tumour size } \\
\text { Tumour grade } \\
\text { Tumour stage } \\
\text { beta-blocker treatment }\end{array}$} & 1.985 & 0.004 & 1.248 & 3.159 \\
\hline & 1.904 & $<0.001$ & 1.435 & 2.526 \\
\hline & 1.565 & $<0.001$ & 1.218 & 2.011 \\
\hline & 0.291 & 0.007 & 0.119 & 0.715 \\
\hline \multicolumn{5}{|l|}{ DM } \\
\hline \multirow{4}{*}{$\begin{array}{l}\text { Tumour size } \\
\text { Tumour grade } \\
\text { Tumour stage } \\
\text { beta-blocker treatment }\end{array}$} & 1.916 & 0.005 & 1.221 & 3.005 \\
\hline & 1.519 & 0.002 & 1.171 & 1.971 \\
\hline & 1.624 & $<0.001$ & 1.270 & 2.076 \\
\hline & 0.430 & 0.031 & 0.200 & 0.926 \\
\hline
\end{tabular}

Table 4: The effect of beta-blocker treatment on breast cancer specific survival (BCSS) and distant metastasis (DM) formation was compared with tumour size, grade and stage to determine the relative risk (Hazard Ratios (HR)) in BC patients. 


\section{REFERENCES}

1. Statistics NOf, http://www.statistics.gov.uk/cci/nugget. asp?id=575. 2010.

2. Cleator SJ, Ahamed E, Coombes RC, Palmieri C, A 2009 Update on the Treatment of Patients with Hormone Receptor-Positive Breast Cancer. Clinical Breast Cancer 2009;9: S6-S17.

3. Rosen LS, Ashurst HL, Chap L, Targeting Signal Transduction Pathways in Metastatic Breast Cancer: A Comprehensive Review. Oncologist;15: 216-235.

4. Spears M, Bartlettt J, The potential role of estrogen receptors and the SRC family as targets for the treatment of breast cancer. Expert Opinion on Therapeutic Targets 2009; 13: 665-674.

5. Johnston SRD, Enhancing the Efficacy of Hormonal Agents with Selected Targeted Agents. Clinical Breast Cancer 2009;9: S28-S36.

6. Sporn MB, The war on cancer. Lancet 1996;347: 13771381.

7. Lang K, Drell TL, Zaenker KS, Entschladen F, Inhibitors for metastasis development. Recent Patents on Anti-Cancer Drug Discovery 2006;1: 69-80.

8. Sleeman J, Steeg PS, Cancer metastasis as a therapeutic target. Eur J Cancer;46: 1177-1180.

9. Entschladen F, Drell TL, Lang K, Joseph J, Zaenker KS, Tumour-cell migration, invasion, and metastasis: navigation by neurotransmitters. Lancet Oncol 2004;5: 254-258.

10. Entschladen F, Drell TL, Lang K, Joseph J, Zaenker KS, Neurotransmitters and chemokines regulate tumor cell migration: potential for a new pharmacological approach to inhibit invasion and metastasis development. Curr Pharm Des 2005;11: 403-411.

11. Masur K, Niggemann B, Zanker KS, Entschladen F, Norepinephrine-induced migration of SW 480 colon carcinoma cells is inhibited by beta-blockers. Cancer Res 2001;61: 2866-2869.

12. Lang $\mathrm{K}$, Drell TL, Lindecke A, Niggemann B, Kaltschmidt C, Zaenker KS, Entschladen F, Induction of a metastatogenic tumor cell type by neurotransmitters and its pharmacological inhibition by established drugs. Int J Cancer 2004;112: 231-238.

13. Sood AK, Bhatty R, Kamat AA, Landen CN, Han L, Thaker PH, Li Y, Gershenson DM, Lutgendorf S, Cole SW, Stress hormone-mediated invasion of ovarian cancer cells. Clin Cancer Res 2006;12: 369-375.

14. Drell TL, Joseph J, Lang K, Niggemann B, Zaenker KS, Entschladen F, Effects of neurotransmitters on the chemokinesis and chemotaxis of MDA-MB-468 human breast carcinoma cells. Breast Cancer Res Treat 2003;80: 63-70.

15. Palm D, Lang K, Niggemann B, Drell TL, Masur K, Zaenker KS, Entschladen F, The norepinephrine-driven metastasis development of $\mathrm{PC}-3$ human prostate cancer cells in BALB/c nude mice is inhibited by beta-blockers. Int J Cancer 2006;118: 2744-2749.

16. Al-Wadei HA, Al-Wadei MH, Schuller HM, Prevention of pancreatic cancer by the beta-blocker propranolol. AntiCancer Drugs 2009;20: 477-482.

17. Zhang D, Ma QY, Shen SG, Hu HT, Inhibition of Pancreatic Cancer Cell Proliferation by Propranolol Occurs Through Apoptosis Induction The Study of beta-Adrenoceptor Antagonist's Anticancer Effect in Pancreatic Cancer Cell. Pancreas 2009;38: 94-100.

18. Klapholz M, beta-Blocker Use for the Stages of Heart Failure. Mayo Clinic Proceedings 2009;84: 718-729.

19. Weber R, Weimar C, Diener HC, Medical prevention of stroke and stroke recurrence in patients with TIA and minor stroke. Expert Opinion on Pharmacotherapy 2009;10: 1883-1894.

20. Fryzek JP, Poulsen AH, Lipworth L, Pedersen L, Norgaard M, McLaughlin JK, Friis S, A cohort study of antihypertensive medication use and breast cancer among Danish women. Breast Cancer Res Treat 2006;97: 231-236.

21. Li CI, Malone KE, Weiss NS, Boudreau DM, CushingHaugen KL, Daling JR, Relation between use of anti hypertensive medications and risk of breast carcinoma among women ages 65-79 years. Cancer 2003;98: 15041513.

22. Dhabhar FS, Enhancing versus Suppressive Effects of Stress on Immune Function: Implications for Immunoprotection and Immunopathology. Neuroimmunomodulation 2009; 16 : 300-317.

23. Slotkin TA, Zhang JA, Dancel R, Garcia SJ, Willis C, Seidler FJ, beta-adrenoceptor signaling and its control of cell replication in MDA-MB-231 human breast cancer cells. Breast Cancer Res Treat 2000;60: 153-166.

24. Vandewalle B, Revillion F, Lefebvre J, Functional BetaAdrenergic Receptors in Breast-Cancer Cells. J Cancer Res Clin Oncol 1990;116: 303-306.

25. Shang ZJ, Liu K, Liang DF, Expression of beta(2)adrenergic receptor in oral squamous cell carcinoma. Journal of Oral Pathology \& Medicine 2009;38: 371-376.

26. Fitzpatrick AL, Daling JR, Furberg CD, Kronmal RA, Weissfeld JL, Hypertension, heart rate, use of antihypertensives, and incident prostate cancer. Annals of Epidemiology 2001;11: 534-542.

27. Harris AM, Warner BW, Wilson JM, Becker A, Rowland RG, Conner W, Lane M, Kimbler K, Durbin EB, Baron AT, Kyprianou N, Effect of alpha 1-adrenoceptor antagonist exposure on prostate cancer incidence: An observational cohort study. Journal of Urology 2007;178: 2176-2180.

28. Martin FM, Harris AM, Rowland RG, Conner W, Lane M, Durbin E, Baron AT, Kyprianou N, Decreased risk of bladder cancer in men treated with quinazoline-based alpha 1-adrenoceptor antagonists. Gene Therapy and Molecular Biology 2008;12B: 253-257.

29. Algazi M, Plu-Bureau G, Flahault A, Dondon MG, Le MG, 
Is beta-blocker treatment associated with a decrease in the risk of cancer. Letters in Drug Design \& Discovery 2006;3: 653-661.

30. El-Rehim DMA, Ball G, Pinder S, Ellis IO, Molecular classification of breast carcinoma based on the protein expression immunoprofiles. J Pathol 2004;204: 3A-3A.

31. Blamey RW, Ellis IO, Pinder SE, Lee AHS, Macmillan RD, Morgan DAL, Robertson JFR, Mitchell MJ, Ball GR, Haybittle JL, Elston CW, Survival of invasive breast cancer according to the Nottingham Prognostic Index in cases diagnosed in 1990-1999. Eur J Cancer 2007;43: 1548-1555. 